\title{
Rad concept: authentic evidence women's specialties in Islamic heritage law
}

\author{
Muhibbussabry \\ Faculty of Shariah and Law, UIN Sumatera Utara, Medan. Indonesia \\ Jl. William Iskandar Ps. V, Medan Estate, Kec. Percut Sei Tuan, \\ Kabupaten Deli Serdang, Sumatera Utara 20371 \\ Email:muhibbussabry@uinsu.ac.id
}

\begin{abstract}
Abstrak
Pada prinsipnya, Islam adalah agama yang menegaskan adanya kesetaraan dan kesejajaran antara laki-laki dan perempuan yang menempatkan perempuan pada posisi yang adil untuk mendapatkan hak-haknya dalam bidang sosial, ekonomi dan politik, termasuk dalam Hukum waris Islam. Penelitian ini bertujuan untuk menjawab bias gender dengan mendeskripsikan keistimewaan perempuan di dalam konsep rad terhadap hukum kewarisan Islam. Penelitian ini menggunakan metode deskriptif analitik dengan pendekatan normatif, yuridis dan historis. Pada masa Jahiliyah, perempuan tidak mendapatkan harta warisan, bahkan mereka bebas untuk diperjual belikan. Islam datang mengubah tradisi tersebut dan memberikan bagian warisan untuk perempuan, dengan kadar setengah dari bagian laki-laki. Namun, para aktivis gender berdalih ini bentuk diskriminasi terhadapat perempuan dan menolak bagian kewarisan yang telah ditetapkan dalam agama Islam tersebut. Hasil dari penelitian ini adalah melalui konsep rad, yaitu ketika terdapat sisa harta setelah diambil oleh penerima bagian tetap (așhābul furūọ), maka sisanya menurut jumhur ulama diberikan kepada seluruh ahli waris dari golongan perempuan, ini membuktikan bahwa hukum waris Islam dari awal mula lahir untuk mengangkat harkat dan derajat kaum perempuan sampai dengan sekarang masih memberikan keistimewaan dan kemaslahatan besar bagi perempuan.
\end{abstract}

Kata Kunci: keistimewaan perempuan, hukum waris Islam, konsep rad, bias gender.

\begin{abstract}
Basically, Islam is a religion explains existence of equivalents and parallelization between man and woman which placed woman in a fair position to get her rights in social, economy, politic, and Islamic inheritance law. This study aims to answer gender bias in the manner of describing woman uniqueness in rad concept by Islamic inheritance law. This study uses descriptiveanalytic method via normative, juridical, and historical approachment. In jahiliah period, a woman did not get inheritance, even they are commercialized publicly. Islam comes to change that tradition and gives inheritance for her by value a half from man. But, some gender activists argue this statement and say it as discrimination shape for woman, and they disagree with that. This study result shows in rad concept, when there is still treasure rest after be taken by permanent inheritor (așhābul furūd), according to jumhur ulama that rest is given to all woman inheritors. This proves that Islamic inheritance law comes to glorify woman status and dignity from the beginning till now in giving uniqueness and goodness for woman.
\end{abstract}

Keywords: woman uniqueness, Islamic Inheritance Law, Rad concept, gender bias.

\section{Introduction}

$\mathbb{Q}$ 1-Qur'an as the main source of Islamic teachings has emphasized the equality and alignment between men and women which places women in a fair position to obtain their rights in the social, economic and political fields. Normatively, the Qur'an has emphasized equality between men and women, but textually the Qur'an also states that men have advantages over women 
as in the distribution of inheritance. Men get a greater share than the share received by women. As in surah an-Nisa 'verse 11: "The portion of a son is the same as the part of two daughters". Likewise in surah an-Nisa 'verse 176: "and if they (heirs are made up of) brothers and sisters, then the portion of a brother is as much as the portion of two sisters". The Qur'an also states that men are leaders for women, which is contained in surah an-Nisa 'verse 34 .

In its development, many gender activists have sued and claimed that Islamic inheritance laws tend to be gender biased, ${ }^{1}$ act unfairly and discriminate against women's rights, one of which is through the difference in the ratio of parts accepted by men and women with a rate of two to one (2:1). Some figures who issued lawsuits and criticisms of Islamic inheritance law include: Aminah Wadud, ${ }^{2}$ Muhamad Syahrur, ${ }^{3}$ Asghar Ali Engineer, ${ }^{4}$ Musdah Mulia ${ }^{5}$ and Munawir Syadzali. ${ }^{6}$ The

${ }^{1}$ Gender is a concept used to identify differences between men and women in terms of social culture. So it is more directed at defining men and women from a non-biological perspective. See Nasaruddin Umar, Argumen Kesetaraan Gender Perspektif Al-Qur'an, 2nd ed. (Jakarta: Paramadina, 2001), p. 35.

${ }^{2}$ Aminah Wadud, argues that the provision of inheritance (2:1) is not an absolute provision, but only a variation of the division. According to him, the distribution of inheritance should be done with a variety of considerations, including the condition of the family left behind, the principle of the benefits and needs of the heirs as well as the benefits of the inheritance itself. So, according to Aminah, that the distribution of inheritance can be very flexible and has many possibilities of distribution, depending on the benefits of property for each heir. If so, then the division reflects the nature of justice. Amina Wadud, Qur'an Menurut Perempuan: Meluruskan Bias Gender Dalam Tradisi Tafsir . Terj. Abdullah Ali (Jakarta: Serambi, 2001), p. 156.

${ }^{3}$ Muhammad Syahrur, fiqh scholars read the sentence مثل with the harakat dammah, thus giving rise to the understanding that the portion of a boy is equal to twice the portion of a girl. The verse should be read fathah, so that it is understood the part of boys such as part two of girls. Muḥamad Syaḥrūr, Naḥwu Ușūl Jadīdah Li Al-Fiqh Al-Islāmī: Fiqh Al-Mar'ah (Damaskus: al-Ahālī li alTibā'ah wa al-Nasyr wa al-Tauzī', 2000), p. 221.

${ }^{4}$ Asghar Ali Engineer argues that the part comparison (2: 1) is not a final determination. According to Engineers Muslims need to carry out methodological reconstruction in understanding the Qur'an. The Scriptures must be interpreted in two aspects, namely the normative aspect and the contextual aspect. These two aspects become important due to the fact that there are differences in the concepts and practices of Islamic law in various parts of the world. This shows that first, the difference is more due to socio-political conditions. Secondly, these different conditions make it necessary to reconstruct the interpretation of the Qur'an which (as if) gender is not fair to be in accordance with their respective contexts. So that religion will be judged to be dynamic, flexible and able to accept change. Read Asghar Ali Engineer, The Qur'an Women and Modern Society . Terj. Agus Nuryanto, "Pembebasan Perempuan" Cet. Ke-1 (Yogyakarta: LKIS, 2003), p. 41. Also read Asghar Ali Engineer, Hak-Hak Perempuan Dalam Islam, Terj. Farid Wajidi Dan Cici Farkha Assegaf, Cet. I (Yogyakarta: Yayasan Bentang Budaya, 1994), p. 101-106.

${ }^{5}$ Musdah Mulia thinks that men and women are no different, there is no number one and there is no primary, because only God is number one and primary. Then the context with the distribution of inheritance (2: 1) is very unfair. Marwan Sarijo, Cak Nur Diantara Sarung Dan Dasi Dan Musdah Mulia Tetap Berjilbab, Catatan Pinggir Sekitar Pemikiran Islam Di Indonesia (Jakarta: Yayasan Ngali Aksara Penamadani, 2005), p. 74.

${ }^{6}$ According to Munawir, the distribution of inheritance (2:1) does not reflect the spirit of justice for the people of Indonesia today. This is evidenced by the many deviations from the provisions of the inheritance, both perpetrators and scholars do. In addition, the division of inheritance is a gradual Islamic teaching. That is, when women in the period of ignorance began to be given inheritance rights by Islam (even though only half of the men), women were appointed to 
gender activists, asked to re-interpret the laws of Islamic inheritance. So that Islamic inheritance law must be able to accommodate the needs of society and provide justice to women in the present.

Some of these criticisms are actually an accusation that is not fundamental, as well as reflecting their lack of understanding of the essence of Islamic inheritance law. There are many studies that have been discussed and at the same time maintain the essence of Islamic inheritance law in terms of differences in the division obtained between men and women (2:1).

Fakhruddin ar-Rāzì interprets verses related to the inheritance section by issuing a statement that the part that Allah has assigned to all heirs is more important than the part determined later by humans, because Allah is AllKnowing all the provisions, knowing which is greater benefit and mafsadat . Likewise, Allah the Most Wise does not command unless it is something that brings great benefit and benefit to humans. So in any circumstance carrying out the order of distribution of inheritance in accordance with what has been determined by God it is more important than following the human policy that there must be a mistake and wrong, this is in line with the words of God to the Angels in surah al-Baqarah verse 30: "Actually I know better what you don't know."

Sayyid Qutub also interpreted the verse "Verily, Allah is All-Knowing, AllWise", to remind people, that every provision of Allah for humans is the full right of Allah that should not be taken over by anyone from His creatures. Likewise benefit will be realized due to the perfect knowledge and wisdom of Allah Almighty. Allah determines the decision because Omniscient while humans do not, Allah has obliged the distribution of inheritance because of Wisdom, while if handed over to humans, of course humans will always follow their desires. ${ }^{8}$ Thus, the difference in the portion of inheritance of men and women is not due to gender, social and cultural factors. The proof after Islam came, women also get a share of inheritance, as well as men. However, what is the wisdom behind the decree of God, among them because men are heavier than the women dependents. Like making a living to spend his family life, his children and the people who are dependents syar'i. Even men are responsible for all special and general problem arrangements. ${ }^{9}$

From the above opinions, it can be understood that the arguments presented by gender activists, Aminah Wadud, Muhamad Syahrul, Asghar Ali Engineer, Musdah Mulia and Munawir Syadzali above proved to be weak, because the determination of the inheritance itself was considered final (QS. Nisa 'verses

the rank. Appointment of this woman's degree is not done directly, but in stages. This is in accordance with the gradual nature of Islamic teachings as in the case of prohibiting khamr. Another reason, is that in modern times, women have the same role as men in society. It is logical if then women have the same inheritance rights as men. Munawir Sjadzali, Kontekstualisasi Ajaran Islam (Jakarta: Paramadina, 1995), p. 88.

${ }^{7}$ Fakhruddin Al-Rāzī, Mafātīḥ̄ Al-Ghaib Jilid IX (Beirut: Dār Ihyā̄' al-Turās al-'Arabī, 1420), p. 520.

${ }^{8}$ Sayyid Quțub, Fi Żilāl Al-Qur'an, Jilid I (kairo: Dār al-Syurūq, 1980), p. 593.

${ }^{9}$ Muchamad Coirun Nizar and Rozihan Rozihan, "PEMAHAMAN HOLISTIK TENTANG HUKUM WARIS ISLAM: PERSPEKTIF FILOSOFIS," Indonesian Journal of Islamic Literature and Muslim Society, 2019, doi:10.22515/islimus.v3i1.1213, p. 51. 
13 and 14), also in understanding inheritance rights, they use an equality perspective not a justice perspective. Where one of the meanings of fair is balance. ${ }^{10}$ This means fulfilling the rights of each part in a system very well. Granting inheritance to boys is twice as large as girls based on the balance of the relationship system in the family that is closely related to the obligations of men in terms of supporting the family. ${ }^{11}$ The two larger parts owned by the man are actually to be given to his wife and family, while the woman who only receives one part is not the case, the property is only his. If the woman marries, her husband's living needs will be borne by her husband, while the share can be saved without the need to spend. If you see whose assets are used up first and who are still intact, then the answer is clear, the ones that are more quickly used up belong to men, because the two parts they get must be further divided, while what women has is not used at all. ${ }^{12}$

This was also reinforced by Șalāhuddin Sulțān, after conducting an in-depth study of the inheritance conditions of men and women, he concluded that about 30 problems over women took equal shares with men, or more than men, or women can a male inheritance not. Only in the four issues that the female portion is half of the male portion, for reasons that meet the needs, complement each other in balance through the duties and responsibilities of men towards women are greater. ${ }^{13}$

From various existing research results, many have discussed and at the same time maintained the essence of Islamic inheritance law in terms of the different parts obtained between men and women (2:1). So that in this study, the author will describe the other side, namely women's privileges in the concept of rad to Islamic inheritance law, so that all gender biases voiced by gender activists

${ }^{10}$ The word "fair" has various meanings according to the context and purpose of its use. At least there are four meanings according to religious experts. First, fair in the same sense. Second, fair in the sense of being balanced. Third, fair is attention to individual rights and give those rights to each owner. Fourth, justice attributed to Divine M. Quraish Shihab, Wawasan Al-Qur'an: Tafsir Maudhu'i Atas Berbagai Persoalan Umat, Cet. Ke-7 (Bandung: Mizan, 1998), p. 110-126. In relation to rights concerning material matters, especially those relating to inheritance law, fair can be interpreted as a balance between rights and obligations and a balance between those obtained with needs and uses. See Amir Syarifudin, Pelaksanaan Hukum Kewarisan Islam Dalam Lingkungan Adat Minangkabau, Cet. Ke-1 (Jakarta: Gunung Agung, 1984), p. 115.

${ }^{11}$ The provisions of the inheritance section in Islam are based on several factors. First, the level of kinship between the heirs (both male and female) and the person who died. The closer the kinship, the greater the share of inheritance received. Second, generation level position. The younger generation of heirs whose future is still long sometimes get a bigger share than the older generation, regardless of their maleness or femininity. Three, the responsibility to bear family life. It is this point that sometimes distinguishes the portion of inheritance rights between men and women, even though they are at the same level of kinship. Because the position of a son bears the livelihood of his wife and family. While women are not charged with these responsibilities. See, Muhammad Imarah, Introduction to Șalāḥuddin Sulțān, "Mirās Al-Mar'ah Wa Al-Qaḍiyyah Al-Musāwah.Pdf" (Mesir: Dār Nahḍah, 1999), p. 4.

${ }^{12}$ M. Quraish Shihab, Perempuan Dari Cinta Sampai Seks, Dari Nikah Mut'ah Sampai Nikah Dari Bias Lama Sampai Bias Baru (Jakarta: Lentera Hati, 2005), p. 262.

${ }^{13}$ Sulțān, "Mirās Al-Mar'ah Wa Al-Qadìyyah Al-Musāwah.Pdf", p. 18-46. 
can be refuted, and know how the rules set by God contain benefits for all humans without benefit discriminating sex between men and women.

\section{Research method}

This research uses a descriptive analytic method that begins by describing the concept of $\mathrm{rad}$, the thoughts of fiqh scholars about the concept of rad then the authors try to analyze the privilege of women in the concept of rad against Islamic inheritance law. In this study the authors used three approaches. First, normative (theory) approach, juridical approach, and historical approach. This study uses a qualitative analysis method. Qualitative analysis method is a research procedure that produces descriptive data in the form of written or spoken words from people and observable behavior. ${ }^{14}$ Qualitative research methods in this discussion by presenting the analysis in the form of a description of written words and not in the form of numbers. The results of the analysis and discussion are then written in the form of a research report which is described in full, detailed, clear and systematic. The analytical method used in this study is the inductive method, which is the taking of understanding and ways of completing each other between the analysis process that departs from specific events and then concludes in general. ${ }^{15}$ This method is used in order to obtain a complete picture of the privilege of women in the concept of rad to Islamic inheritance law.

\section{Opinions of Ulama about Rad}

Rad etymologically has several meanings, including: al-șarfu (exchange), al$i_{i j a}{ }^{\prime} u$ (return), al-i'ädah (addition), al-rafḍu (rejection) and al-man'u (prevention). ${ }^{16}$ While rad in terminology is the opposite of 'aul, ${ }^{17}$ namely the reduction in the number of shares (shares) of heirs and the increase in origin of inheritance problems. ${ }^{18}$ Or rad is returning what is left of the fixed portion (așhäbul fur $\bar{u} d$ ) to them according to the size of their portion if there is no așhab al-'așabah (residual recipient)..$^{19}$ Thus it can be concluded that what is meant by rad is the return of the remaining portion after being taken by the recipient of the permanent portion (așhäbul furū there is no recipient of the remaining portion ('așabah).

${ }^{14}$ Lexy. J. Moleong, Metodologi Penelitian Kualitatif, Cet. Ke 14 (Bandung: Remaja Rusda Karya, 2001), p. 8.

${ }^{15}$ Sukandarrumidi, Metodologi Penelitian: Petunjuk Praktis Untuk Peneliti Pemula , Cet. Ke-2 (Yogyakarta: Gajah Mada University Press, 2008), p. 38.

${ }^{16}$ Ibnu Manżūr Al-Ifrīīi, Lisān Al-'Arab Jilid V (Beirut: Dār al-Ihyā̄' al-Turās̄ al-Islāmī, 1419), p. 84.

17 'Aul in terminology is the increase in shares (parts) of the problem from the original, which reduces the portion that will be received by the heirs. It was said ul aul because in the practice of inheritance distribution, the number of origin of the problem had to be increased or increased by the number of parts received by the existing heirs. This step was taken, because if the distribution of inheritance is completed according to the proper provisions, there will be a shortage of assets. See 'Ali bin Muhammad Al-Jarjānī, Al-Ta'rîfāt (Beirut: Dār al-Kitāb al' Arabī, 1413), p. 205.

${ }^{18}$ Muhammad Amin, Raddu Al-Muhtēor 'ala Al-Durrī Al-Mukhtār, Jilid VI (Beirut: Dār al-Fikr, 1386), p. 787.

${ }^{19}$ Al-Jarjānī, Al-Ta'rīfāt, p. 147. 
Regarding this concept of rad, the scholars also differed, considering that there is no specific naș contained in the Qur'an and al-Hadis concerning rad. Whether the rad is there or not, but in the opinion of the räjih (strong), even today it has become a reference in the resolution of rad cases, states that the rad exists. For more details, the opinion of scholars in this case is divided into two, namely as follows.

1. Opinions of Zaid bin Sabit, Urwah, az-Zuhri, Imam Malik, Imam Shafi'i and Ibn Hazmin al-Żāhirī, that there is no rad in inheritance inheritance and the remaining assets after being taken by the recipient of a fixed portion (așhābul furū $)_{\text {) }}$, handed over to Baitul Mal. ${ }^{20}$ The first basis of opinion refers to surah an-Nisa' verses 13 and 14, as well as the words of the Prophet Muhammad:

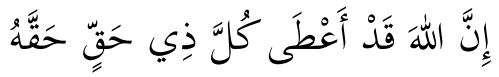

"Verily, Allah has given everyone who has the right to his property". ${ }^{21}$

The verse and hadis indicate a prohibition beyond the prescribed boundary and the predetermined part. Therefore, rad is forbidden and should not be done. So that the remaining assets after being taken by the recipient of the fixed portion (așhābul furūọ), if there is no 'așabah (residual recipient) is returned to the Baitul Mal.

2. Opinions of Jumhur Sahabat and Tabi'in consisting of Ali ibn Abi Talib, Umar bin Khattab, Usman bin 'Affan, and 'Abdullah bin Mas'ud, as well as the Hanafiyah and Hanabilah schools, argued that the remainder after being taken by the recipient of a permanent portion (așhābul furūd ), if there is no residual recipient ('așabah) then it is returned to așhābul furū respective portions. ${ }^{22}$ The legal basis for this opinion is surah al-Anfal verse 75 :

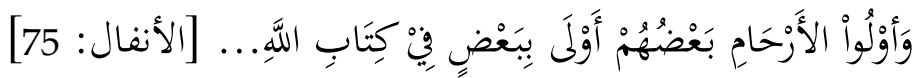

"Some people who have relatives are more entitled to each other (than non-relatives)".

This verse has a general meaning, that everyone who is bound by the uterine relationship is more likely to receive an inheritance than others. Thus, they have the right to take the rest of the inheritance. This verse also does not contradict the inheritance verse, because the predetermined portion has been given to așhābul furū $d$. So that it can be understood that taking the remaining parts is not adding to the part that God has determined, but because there are other causes, such as people inheriting because of kinship through two channels. In addition, there are traditions related to the inheritance of the Prophet who experienced Sa'ad bin Abi Waqqas who explained that the Prophet. does not forbid Sa'ad, who limits inheritance to his daughters only.23

${ }^{20}$ Komite Fakutas Syari'ah Universitas Al-Azhar, Fiqh Al-Mawarits (kairo: Lajinah Kuliah Syari'ah wal Qanun, 2010), p. 265.

${ }^{21}$ Issued by Ibn Majah in the will, the chapter no will for heirs, hadith no. 2713. See Muhammad bin Yazid bin Majah, Sunan Ibnu Majah (Riyaḍ: Dār al-Salām, 1420), p. 390-391.

${ }_{22}$ Al-Azhar, Fiqh Al-Mawarits, p. 266.

${ }^{23}$ Issued by Bukhari in the Book of a will a third testament of a will. Hadith no. 2744. See Ahmad bin 'Ali bin Hajar Al-'Askalani, Fathu Al-Bāri Bi Syarhi Shahih Al-Bukhāri, Jilid V (kairo: Dār al-Riyani li al-Turaś, 1409), p. 434-435. See also Al-Azhar, Figh Al-Mawarits, p. 267. 
Another reason used as the basis for the opinion of jumhur ulama is that așhābul furū d (fixed part recipient) is more entitled than baitul mal, because the position of așhābul furū religion and the people. While leaving the rest to baitul mal was only for one reason, namely kinship with religion. So that the remainder of the portion after being taken by the recipient of the permanent part is more entitled and the main is given to them the recipient of the permanent part (așhäbul furūd ) rather than to the baitul mal.

With a variety of propositions that are used, then the opinion that is authentic (strong) in the opinion of the author is the second opinion that says the existence of rad, where the rest after taken by all recipients of fixed parts (așhäbul furū nisbat. Other indications, historically also marked by the persistence of the term rad to the present and the concept of rad is used in the settlement of cases of inheritance in the Islamic world, especially in Indonesia.

Although the companions of Jumhur agree on rad, that is when there is left over assets, returned to aṣhābul furū disagree about which așhābul furū after they have taken part. Divided into four opinions of the scholars, namely:

1. Opinion of Ali ibn Abi Talib, Umar bin Khattab, jumhur companions and tabi'in, Hanafiyah, Hanābilah and the next generation of Shafi'i scholars, that the remaining rad property is not handed over except to așhäbul furū and should not be handed over for așhābul furū is husband or wife. ${ }^{24}$

2. The opinion of Usman bin 'Affan that the return of the remainder was given to all recipients of the fixed portion (așhābul furū reasoned that the husband or wife also bears the shortfall on their part when the 'aul case occurs, they are also obliged to receive extra when there is a residual return, because giving debts there must always be a return..$^{25}$

3. Opinion of Ibn 'Abbas, that the return of the remaining rad is left to așhäbul furüd besides husband and wife and grandmother, if the grandmother is with the recipient of a permanent part who has a kinship because of the nasab. If there isn't, grandma can get the rest of the return through the rad. The evidence used by Ibn Abbas is the words of the Prophet. "Feed the grandmothers with onesixth part (1/6)". So that the grandmother may not get more than what is specified, unless there is no așhābul furū d who has a kinship because of the passage. ${ }^{26}$

4. The opinion of Ibn Mas'ud, 'Alqamah, Imam Ahmad bin Hanbal in some unfamiliar narrations, that there is no return of the rest to the six groups of așhābul furūd, namely husband, wife, grandmother, granddaughter of sons, sisters seapak and brothers and sisters. ${ }^{27}$

${ }^{24}$ Al-Azhar, Fiqh Al-Mawarits, p. 268.

${ }^{25}$ Ibid., p. 268.

${ }^{26}$ Ibid., p. 268.

${ }^{27}$ Ibid., p. 269. 
Some of the conditions for the occurrence of rad cases include:

1. The existence of the remaining inheritance after being taken by așhābul furū

2. The absence of 'asabah (residual recipient), because if there will take the remaining assets in full.

3. The existence of așhābul furūd receiving rad, except husband and wife. ${ }^{28}$

If the three inheritance requirements are not found in the distribution of inheritance, or there is only one of these cases, then the case is not called the case of $\mathrm{rad}$, but the case 'adilah (ordinary).

In the opinion of Usman bin Affan who was also adopted by the Compilation of Islamic Law, rad can occur in all așhāabul furūḍ, including husband and wife. While Jumhur Ulama that rad can occur in all așhābul furūẹ except husband and wife. Thus the recipients of the rad part (așhäbul rad), numbering eight people, namely:

1. Daughter

2. Grand daughter of a son

3. Natural sister

4. Sister in law

5. Mother

6. Grandmother from the father or mother

7. A thousand sisters

8. A thousand brothers.

As for fathers and grandfathers, even though both are included in așhābul furū $\underline{d}$ in certain circumstances, they cannot get rad. Because in any case, if there is one inheritance in the distribution of inheritance, then there is no possibility of $\mathrm{rad}$, because both of them receive inheritance as 'așabah, they will get the remaining inheritance.

The case of rad is included in the chapter of Islamic inheritance which is accommodated by its provisions in the Compilation of Islamic Law. The Compilation of Islamic Law states, when a case of rad occurs then it is settled as the sound of article 193 namely:

"If the distribution of inheritance among heirs "zawil furud" shows that the numerator is smaller than the denominator, while there are no heirs, then the distribution of inheritance is carried out radically, in accordance with the rights of each heir, while the rest is divided equally between them".

Thus this is in line with the opinion of Usman bin 'Affan who returned the remaining $\mathrm{rad}$ to all existing heirs without exception. This is seen as closer to justice for all existing heirs, especially husband or wife when in the case of lack of property ('aul) they also bear the shortage, so it is appropriate if there is a case of excess assets $(\mathrm{rad})$, they are also the recipients the rest of the treasure after taking part remains.

${ }^{28}$ Nașhir bin Muhammad Bin Musyarī Al-Ghāmid̄̄, Al-Khullașah Fi 'Ilmi Al-Faraị̣ (Mekah: Dār Ṭibah al-Khuḍarā, 2007), p. 381. 


\section{Types of Rad cases and methods of resolution}

Rad problems are divided into two types, and in each of these types there are many conditions, where in each situation there is a separate method for its resolution. As the following explanation.

1. In a case there is no husband or wife, and this case is a variety of rad problems, not apart from three circumstances.

a. Așhābul furū fard and rad lines (receiving the fixed portion first then remaining).

For example, someone dies and leaves an heir of a daughter.

\begin{tabular}{|c|c|c|c|}
\hline Heir & Part & 2 & 1 \\
\hline Girl & $1 / 2$ & 1 & 1 \\
\hline
\end{tabular}

Note: One daughter gets a fixed portion $1 / 2$, then the remaining $1 / 2$ is also returned to her by the rad line.

b. Așiābul furū d are many, but they have the same fixed parts. Then the completion method is as follows:

1) The origin of the problem is taken from the number of heirs, and the remaining inheritance for all of them by way of fardan wa raddan (taking a fixed portion first then remaining).

For example, the heirs left by 5 siblings.

\begin{tabular}{|c|c|c|c|}
\hline Heir & Part & 3 & 5 \\
\hline 5 Sister & $2 / 3$ & 2 & 1 \\
\hline
\end{tabular}

Note: 5 siblings get a $2 / 3$ portion, as long as the problem is 3 . They take 2 parts, so there is still 1 more part. It is known that this is the case of rad. Then the solution by looking at the number of heirs, then used as the origin of the problem that is 5 , each one of the sisters can be 1 part, through the way fard (fixed part) and rad (return).

c. Așhābul furū d are many, but they have different fixed parts. The solution method is as follows:

1) Give a part to all existing heirs.

2) Then determine the origin of the problem, and give the rest of the return to așhäbul furūd, with the origin of the new problem taken from their majmin's siham (sum of shares).

3) Mentașhìh..$^{29}$ if the case is necessary to be corrected.

For example, the heirs left are daughters, mothers and grandchildren of sons.

\begin{tabular}{|c|c|c|c|}
\hline Heir & Part & 6 & 5 \\
\hline Daughter & $1 / 2$ & 3 & 3 \\
\hline Granddaughter & $1 / 6$ & 1 & 1 \\
\hline Mother & $1 / 6$ & 1 & 1 \\
\hline
\end{tabular}

${ }^{29}$ Tashị mas'alah is to find the number of origin of the smallest problem that can produce the heirs' parts without a break number. 
Caption: Daughter gets part $1 / 2$, granddaughter gets part $1 / 6$ and mother has $1 / 6$. The origin of the problem is 6 because of tadākhul. ${ }^{30}$ After being shared with all the heirs, it turns out that there is still 1 part left. So it is known this is a case of rad. And the settlement by means of the total number of shares of all heirs in this case is 5, originating from a new problem. And each heir gets fard (fixed portion) and rad (return). Another example, the heirs left are, a daughter and two granddaughters.

\begin{tabular}{|c|c|c|c|c|}
\hline Heir & Part & 6 & $4^{\times 2}$ & 8 \\
\hline Daughter & $1 / 2$ & 3 & 3 & 6 \\
\hline 2 Granddaughter & $1 / 6$ & 1 & 1 & 2 \\
\hline
\end{tabular}

Note: Daughter get part $1 / 2$, two granddaughters get part $1 / 6$, is a form of tadākhul. So, the origin of the problem is 6 . After dividing by each part there are actually 2 leftovers, it is known that this is a case of $\mathrm{rad}$. The solution is to make the number of their shares 4 , as the origin of new problems. So girls can be part 3, and 2 grandchildren can be part 1 . Because grandchildren number 2 people while their part is 1, if divided will produce a rupture number. Therefore, a tashin al-masalah is needed by multiplying the origin of problem 4 by their number 2 the result is 8 . Then 2 is multiplied by the portion of the heirs namely the daughter portion $3 \times 2=6$, and two granddaughters $1 \times 2=2$, each one people get 1 part.

2. In a case there is a husband or wife, and this case is a variety of rad problems, also can not be separated from the three circumstances.

a. There is a husband or wife together with aşhābul furū solution follows the following steps:

1) The origin of the problem is taken from the denominator (maqam) of the husband or wife. and provide the husband or wife part in accordance with the permanent portion.

2) The remaining time is taken by the husband or wife, given to the existing heirs, through the way fard (fixed portion) and rad (return).

3) In some cases it is necessary to be tașhihh, as if there are a large number of wives, and their shares cannot be distributed because they produce broken numbers. Then it was completed by tașhīh.

For example, someone dies and leaves behind an heir to his wife and daughter.

\begin{tabular}{|c|c|c|c|}
\hline Heir & Part & 8 & 8 \\
\hline Wive & $1 / 8$ & 1 & 1 \\
\hline Daughter & $1 / 2$ & 4 & 7 \\
\hline
\end{tabular}

30 Tadākhul, i.e. larger numbers can be divided by smaller numbers, with the result of division that does not leave a break. For example, if someone dies and leaves behind a daughter's heir, granddaughter and siblings. Then the daughter gets the $1 / 2$ portion, the granddaughter $1 / 6$ and the siblings receive the 'așabah binnafsi portion. If you pay attention to the denominator of the number that is 2 into 6 , because 2 is part of 6 . So this is al-tadākhul and the origin of the problem is from the largest number which is 6 . 
Note: The wife's part is $1 / 8$, daughter $1 / 2$, is a form of tadākhul, so the origin of the problem is 8 . After being divided with each part it turns out that there are remaining 3 parts, so it is known to be a case of rad. The solution is by taking the wife's denominator (maqām), which is 8 as the origin of a new problem. And the wife takes the fixed portion which is $1 / 8$, while the remaining $7 / 8$ is given to girls with the path fard (fixed portion) and rad (return).

Another example, the heirs left are 3 wives and half-sister.

\begin{tabular}{|c|c|c|c|c|}
\hline Heir & Part & 8 & $4^{\times 3}$ & 12 \\
\hline 3 Wive & $1 / 4$ & 2 & 1 & 3 \\
\hline Half Sister & $1 / 2$ & 4 & 1 & 9 \\
\hline
\end{tabular}

Note: Part 3 of the wife is $1 / 4$, half sister $1 / 2$, is a form of tadākhul, as long as the problem is 8 , after dividing by each part there are actually 2 parts remaining, so it is known this is a case of rad. The solution is by taking the denominator (maqām) from 3 wives, namely 4 . Part 3 wife $1 / 4 \times 4=1$, and the sister-in-law portion gets the remainder after being taken by 3 wives, namely 3 parts. But in this case the shares of 3 wives are 1, cannot be divided to 3 people, will result in broken numbers, finally must be tașhīh by multiplying the origin of the problem with their number ('adadadur ruus); $4 \times 3=12$. And the heirs' parts are all multiplied by 3 , which is $1 \times 3=$ 3 for the wife's part 3 , where one person gets 1 part. Then $3 \times 3=9$ for the half-sister, with the path of taking fard first and then the rest (fardan wa raddan).

b. There are husband or wife with many așhābul furū permanent parts. Then the completion method with the steps below:

1) The origin of the problem is taken from the denominator (maqām) of the husband or wife and gives part of the husband or wife in accordance with the fixed part.

2) The remaining time is taken by the husband or wife, given to the existing heirs, through the way fard (fixed portion) and rad (return).

3) In some cases, it is necessary to be tașhìh, then it is resolved by tașhìh. For example, someone dies and leaves an heir, husband and 3 daughters. Their parts are as follows:

\begin{tabular}{|c|c|c|c|}
\hline Heir & Part & 12 & 4 \\
\hline Husband & $1 / 4$ & 3 & 1 \\
\hline 3 Daughter & $2 / 3$ & 8 & 3 \\
\hline
\end{tabular}

Note: The husband can part $1 / 4$, and 3 daughters $2 / 3$, is a form of tabāyun ${ }^{31}$, so the origin of the problem is 12 . After dividing by each section there is leftover 1. It is known that this is the case of rad. The solution, take the husband's denominator namely 4 as the origin of the new problem. And

31 Tabāyun, that is, different numbers which cannot be combined, must be multiplied between the two and the result becomes the origin of the problem. Like $(2,3),(3,4),(3,8)$ and so on. Case in point if the heirs left are mother, wife and biological uncle. Then the mother gets part $1 / 3$, wife is $1 / 4$, and biological uncle takes 'așabah binnafsi. The origin of the problem is $3 \times 4=12$. 
the husband takes the portion $1 / 4 \times 4=1$, while the rest is returned to 3 daughters, namely 3 parts, one person gets 1 share, in a fardan wa raddan manner.

c. There are many husbands or wives with așhäbul furūd, but they have different fixed parts. to complete it by following these steps:

1) Distribute parts like a normal case.

2) If it is clear that the case is rad (more assets), then the origin of the problem is taken from the denominator (maqām) of the husband or wife who is not the recipient of the rad. The rest is then given to aș âbul rad (rad recipient).

3) Next, look for the recipient of $\mathrm{rad}$, where the origin of the problem is taken from their portion, and the sum is added to their shares so that it becomes the origin of the new problem.

4) Then a multiplication is carried out to combine the two (jämi'ah almasalatain).

5) Mentașhīh if the case is necessary to be corrected.

For example, the heirs left are wives, daughters and grandchildren of sons.

\begin{tabular}{|c|c|c|c|c|c|c|c|}
\hline Heir & Part & 24 & 8 & 6 & 4 & $8^{\times 4}$ & 32 \\
\hline Wiev & $1 / 8$ & 3 & 1 & $X$ & $X$ & 1 & 4 \\
\hline Daughter & $1 / 2$ & 12 & \multirow{2}{*}{7} & 3 & 3 & 3 & 21 \\
\hline Granddaughter & $1 / 6$ & 4 & & 1 & 1 & 1 & 7 \\
\hline
\end{tabular}

Note: Medapat's wife is part $1 / 8$, daughter $1 / 2$, and granddaughter $1 / 6$, is a form of tawafuq ${ }^{32}$, the origin of the problem is 24 . After dividing by each part there are remaining 5. So it is known this is a case of $\mathrm{rad}$. The solution is by taking the denominator from the wife, which is 8 as the origin of the problem, the result is that the wife continues to take part 1/8 Remaining $7 / 8$ for rad recipients. Next, it was resolved for the recipient of the rad by seeing the denominators of their parts 2 and 6 are tadäkhul forms, then the origin of the problem was 6 . After being divided by their respective parts, a 3-part daughter was obtained and a 1-part granddaughter, to get the origin of the new problem shares both add $3+1=4$. Then a multiplication is carried out, namely the origin of the problem of the wife part 8 multiplied by the number of shares of recipient $\mathrm{rad} 4,(8 \times 4=32)$, is the origin of the new problem. To get the wife's share, the number of shares of recipient rad 4 is multiplied by the wife's share $1(4 \times 1=4)$, so the wife gets $4 / 32=1 / 8$ (still taking the far part). Then to get the recipient's part of the daughter's rad, that is the rest of the wife's part 7 parts multiplied by the daughter's part $3(7 \times 3=21)$, and grand daughter $(7 \times 1=7)$. They get fard (fixed portion) and rad (return).

32 Tawäfuq, which is mutually adjusting numbers, where the denominator can accept other numbers with an even division, as long as the problem is the result of division with these numbers then multiplied by the denominator. For example, if in one case there are parts $1 / 8$ and $1 / 6$, the two denominator numbers ( 8 and 6 ), can be divided by one number that is 2 . So that the result is the remaining numbers $(8: 2=4)$ and $(6: 2=3)$, then the results $(4$ and 3$)$ are multiplied by the denominator $($ maqām) of the opposite fraction $(4 \times 6=24)$ and $(3 \times 8=24)$. Thus the origin of the problem is 24 . 
- Referring to the Compilation of Islamic Law in Indonesia, the case of rad, after taking a fixed part (fard) of each heir, then the rest is distributed equally according to their respective parts, without distinguishing between husband or wife. This refers to the opinion of Usman bin 'Affan.

For example, a person dies and leaves an heir to his wife, mother and 2 brothers. The assets left are 450 million. What are their respective parts?

\begin{tabular}{|c|c|c|c|}
\hline Heir & Part & 12 & 9 \\
\hline Wive & $1 / 4$ & 3 & 3 \\
\hline Mother & $1 / 6$ & 2 & 2 \\
\hline 2 thousand brother & $1 / 3$ & 4 & 4 \\
\hline
\end{tabular}

Note: After knowing this case is rad, then the origin of the problem is obtained from the total share (share) of all existing heirs namely $(3+2+4=9)$.

\begin{tabular}{|lcc|}
\hline One part content & $=$ property: origin of the problem \\
\hline & $=450$ million: $9=50$ million. \\
\hline Wife's part & $=3 \times 50$ million & $=150$ million \\
\hline Mother's part & $=2 \times 50$ million & $=100$ million \\
\hline Part 2 Brothers & $=4 \times 50$ million & $=200$ million \\
\hline Total & & 450 million \\
\hline
\end{tabular}

So, every 1 brother in a thousand gets 100 million.

\section{Analysis of women's privileges in the concept of Rad}

The concept of rad, which is the result of ijtihad of the ulama in the past, has given a privilege to women, how not as described above, that the heirs of the recipient of the rad (așhābul rad), can be said to be entirely from the female group, namely children daughters, grandchildren of sons, mothers, grandmothers, biological sisters, half-sister, thousand brothers and sisters.

During this time, sometimes in the life of the community still found the impression, if in a family there are no male offspring, then they worry that property will be transferred to the hands of others. Even worse, some are taking steps to divorce for reasons only blessed with daughters only, so afraid of property will be controlled by other parties. It is precisely by exploring this concept of $\mathrm{rad}$, it is known that the female group not only takes a fixed share (fard) but also gets the rest of the return ( $\mathrm{rad}$ ) from the process of inheritance. For example someone dies and leaves one daughter, so the girl takes the regular portion $1 / 2$, while the remaining half (1/2) portion is given to whom? Jumhur ulama agreed the remaining $1 / 2$ portion was also returned to the girl. So he can get all the inheritance. Through the fard and rad paths. The mechanism of the distribution of inheritance using the concept of $\mathrm{rad}$ has also been legalized in the implementation of inheritance law in Indonesia, through Article 193 Compilation of Islamic Law.

Likewise, in this rad concept, at least the form of gender bias that has been championed by gender activists, can be refuted. If someone says that Islam discriminates against women's rights, especially in inheritance law, let us compare the two cases of inheritance that occur, say in two families. The first case, the heirs left only boys, then the portion obtained is 'așabah binnafsi (leftover), if the assets 
left are 100 million, all for the boy. The second case, the heir left behind is the granddaughter of a son, the portion is $1 / 2$, and it is known that this is a case of $\mathrm{rad}$, so that the remaining half is also returned to the granddaughter, say the assets left behind 100 million. Then the grandchild took all the 100 million inheritance by means of fard (fixed portion) and rad (leftover).

From the two case comparisons, it was concluded that there was no difference in terms of the portion received by the male recipient of 'așabah (leftover) from the granddaughter of the son receiving the fixed part (fard) and rad. Both get the same part even though their sexes are different. So where does Islam discriminate against women? Isn't it true that Islam raised the dignity of women from the beginning before the arrival of Islam did not get anything, so that after Islam came women could get a share as men, even women could also take part of the rest, especially in rad cases in inheritance law Islam.

In this life, it is found that cases of heirs who have been cut off for a long time with family, may be his departure to study, jihad, move to a country and so forth. So it is not left in the heir's family, but ahi heirs of the female group only. Well, if after the inheritance is distributed then the judge decides that the missing heir has died (hukmi), because the search deadline has passed the specified time. So, is the remaining wealth after being received by a female heir, then given to someone else, say uncle from the mother (khālun) who is żawil arhām or even handed over to Baitul Mal? The answer is no, because in Indonesia there is a material law that regulates it, and the religious court judges use it. As in KHI Article 193, if there is any remaining assets after being taken by așhābul furū it is returned to the existing heirs. Even before that time, the Companions of the Prophet (PBUH) has resolved the rad case by giving the women the remaining assets after they have taken part in their stays, so this becomes an agreement for jumhur ulama. From this point of view, it is clear that in Islamic inheritance law, women get great features, one of which is in the concept of rad.

Likewise, sometimes there is a case of a new woman converting to Islam, and has no other heirs except from the women's group. When the heir dies and leaves all the female heirs, the heirs who take part remain at the same time get a return in the form of rad. This means that all assets are given to them. For example, the heirs left are biological sisters, mothers, and sisters. What is their respective share if the assets left are 475 million.

\begin{tabular}{|c|c|c|c|}
\hline Heir & Part & $\mathbf{6}$ & $\mathbf{5}$ \\
\hline Mother & $1 / 6$ & 1 & 1 \\
\hline Sister & $1 / 2$ & 3 & 3 \\
\hline A thousand Sister & $1 / 6$ & 1 & 1 \\
\hline
\end{tabular}

From the table above, the mother gets the portion $1 / 6$, the sister is $1 / 2$, and the sister is one thousandth of $1 / 6$, as long as the problem is 6 . After being shared with all the heirs, there are still 1 part remaining. So it is known this is a case of rad. And the settlement by means of the total number of shares of all heirs in this case is 5, originating from a new problem. And each heir gets fard (fixed portion) and rad (return). 


\begin{tabular}{|lcc|}
\hline One part content & $=$ property: origin of the problem \\
\hline & $=475$ million:5 $=95$ million. \\
\hline Mother's part & $=1 \times 95$ million & $=95$ million \\
\hline Sisters part & $=3 \times 95$ million & $=285$ million \\
\hline Part thousand sister & $=1 \times 95$ million & $=95$ million \\
\hline Total & & 475 million \\
\hline
\end{tabular}

Sometimes there are also cases of children born out of wedlock, if the child is female, so in Islamic law, the child's lineage will follow his mother only. ${ }^{33}$ So that when the mother dies and does not leave other heirs except a daughter (girl), the daughter gets a fixed share $(1 / 2)$, and the remaining $(1 / 2)$ is also returned to the child via the rad. Likewise, when her daughter grown up, work, owned a lot of property and passed away, leaving only the maternal heir. Then the mother gets a fixed portion $(1 / 3)$ and the rest $(2 / 3)$ is also returned to the mother via the rad path. So, that all the property left by her daughter belongs to his mother completely.

Below is a table showing the comparison of the parts obtained by male heirs to women, if in each case only one heir left or several heirs from the female group or only men. Where the parts they get are the same, there is no difference between the recipient of the 'așābah and the recipient of the fixed part așhābul fur $\bar{u} d$.

\begin{tabular}{|c|c|c|c|c|}
\hline No & Heir & Part & Heir & Part \\
\hline 1 & Father & All Relics ('Așabah) & Mother & $1 / 3+$ Rad (leftover) \\
\hline 2 & Son & All Relics ('Așabah) & Girl & $1 / 2+$ Rad (leftover) \\
\hline 3 & Brother & All Relics ('Așabah) & Sister & $1 / 2+$ Rad (leftover) \\
\hline 4 & Husband & $1 / 2+$ Rad (leftover) & Wive & $1 / 4+$ Rad (leftover) \\
\hline 5 & $\begin{array}{c}\text { Uncle of } \\
\text { Father } \\
\text { ('Ammun) }\end{array}$ & $\begin{array}{c}\text { All relics because of } \\
\text { Żawil Arḥamm }\end{array}$ & $\begin{array}{c}\text { Aunty from } \\
\text { father }\end{array}$ & $\begin{array}{c}\text { All relics because } \\
\text { of Żawil Arhām }\end{array}$ \\
\hline 6 & $\begin{array}{c}\text { Uncle from } \\
\text { mother } \\
\text { (Khālun) }\end{array}$ & $\begin{array}{c}\text { All relics because of } \\
\text { Żawil Arhām }\end{array}$ & $\begin{array}{c}\text { Aunty from } \\
\text { mather }\end{array}$ & $\begin{array}{c}\text { All relics because } \\
\text { of Żawil Arhām }\end{array}$ \\
\hline
\end{tabular}

From the mentioned table, it's clear that woman gets special position in Islamic inheritance law, because not only man can get inheritance ('așabah), woman can also like that via rad (rest) if someone left by inheritor only female or husband or wife.

\section{Conclusion}

Holy Quran comes with manhaj which is perfect for human life, creating happiness for humans in this world and the hereafter. The characteristics of Islamic law are takāmul (perfect), syumūl (universal), waqi'iyyah (realistic) and tawāzun (balanced). There is no provision about God that does not contain benefit for the life of mankind. So normatively the concept of rad is a concept that gives women the privilege of being able to get more inheritance than predetermined by the nas itself.

\footnotetext{
${ }^{33}$ In the Article 186 of the Compilation of Islamic Law its stated that: "Children born outside of the marriage have only inherited relationships with their mothers and their familys from their mothers."
} 
Likewise juridically in the Compilation of Islamic Law in force in Indonesia article 193 states that if in a case there is an excess of assets, the excess assets are returned to așhābul rad (residual recipient), which in this case is the majority of women. What's more historically the concept of rad has been valid from the time of the Companions of the Prophet. to this day, where the portion obtained by așhābul rad (recipient of rad), is the same as the portion received by the man who took the 'așäbah (leftover) portion. This is at the same time valid proof that Islamic inheritance law highly upholds the dignity of women, brings great benefit to women and can automatically deny allegations of gender bias or discrimination against women.

\section{References}

Al-'Askalani, Ahmad bin 'Ali bin Hajar. Fathu Al-Bāri Bi Syarhi Shahih Al-Bukhāri, Jilid $V$. kairo: Dār al-Riyani li al-Turasं, 1409.

Al-Azhar, Komite Fakutas Syari'ah Universitas. Figh Al-Mawarits. kairo: Lajinah Kuliah Syari'ah wal Qanun, 2010.

Al-Ghāmidī, Nașhir bin Muhammad Bin Musyarī. Al-Khullaṣah Fi 'Ilmi Al-Faraiḍ. Mekah: Dār Ṭibah al-Khuḍarā, 2007.

Al-Ifrīqī, Ibnu Manżūr. Lisān Al-'Arab Jilid V. Beirut: Dār al-Iḥyā' al-Turāṡ al-Islāmī, 1419.

Al-Jarjān̄̄, 'Ali bin Muhammad. Al-Ta'rîfāt. Beirut: Dār al-Kitāb al' Arabī, 1413.

Al-Rāzī, Fakhruddin. Mafātīḥu Al-Ghaib Jilid IX. Beirut: Dār Iḥyā' al-Turās al'Arabī, 1420.

Amin, Muhammad. Raddu Al-Muhtār 'ala Al-Durrī Al-Mukhtār, Jilid VI. Beirut: Dār al-Fikr, 1386.

Engineer, Asghar Ali. Hak-Hak Perempuan Dalam Islam, Terj. Farid Wajidi Dan Cici Farkha Assegaf, Cet. I. Yogyakarta: Yayasan Bentang Budaya, 1994.

- - - The Qur'an Women and Modern Society. Terj. Agus Nuryanto, "Pembebasan Perempuan" Cet. Ke-1. Yogyakarta: LKIS, 2003.

Majah, Muhammad bin Yazid bin. Sunan Ibnu Majah. Riyaḍ: Dār al-Salām, 1420.

Moleong, Lexy. J. Metodologi Penelitian Kualitatif, Cet. Ke 14. Bandung: Remaja Rusda Karya, 2001.

Mulia, Musdah. Muslimah Reformis: Perempuan Pembaru Keagamaan. Bandung: Mizan, 2004.

Nizar, Muchamad Coirun, and Rozihan Rozihan. "PEMAHAMAN HOLISTIK TENTANG HUKUM WARIS ISLAM: PERSPEKTIF FILOSOFIS." Indonesian Journal of Islamic Literature and Muslim Society, 2019. doi:10.22515/islimus.v3i1.1213.

Quțub, Sayyid. Fi Żilāl Al-Qur'an, Jilid I. kairo: Dār al-Syurūq, 1980.

Sarijo, Marwan. Cak Nur Diantara Sarung Dan Dasi Dan Musdah Mulia Tetap Berjilbab, Catatan Pinggir Sekitar Pemikiran Islam Di Indonesia. Jakarta: Yayasan Ngali Aksara Penamadani, 2005.

Shaikh, N.M. Woman in Muslim Society. New Delhi: Kitab Bhavan, 1991.

Shihab, M. Quraish. Perempuan Dari Cinta Sampai Seks, Dari Nikah Mut'ah Sampai Nikah Dari Bias Lama Sampai Bias Baru. Jakarta: Lentera Hati, 2005. 
- - - Wawasan Al-Qur'an: Tafsir Maudhu'i Atas Berbagai Persoalan Umat, Cet. Ke7. Bandung: Mizan, 1998.

Sjadzali, Munawir. Kontekstualisasi Ajaran Islam. Jakarta: Paramadina, 1995.

Sukandarrumidi. Metodologi Penelitian: Petunjuk Praktis Untuk Peneliti Pemula, Cet. Ke-2. Yogyakarta: Gajah Mada University Press, 2008.

Sulțān, Șalāḥuddin. "Mirās Al-Mar'ah Wa Al-Qaḍiyyah Al-Musāwah.Pdf." Mesir: Dār Nahụah, 1999.

Syaḥūr, Muḥamad. Naḩwu Ușūl Jadīdah Li Al-Fiqh Al-Islāmī: Fiqh Al-Mar'ah. Damaskus: al-Ahālī li al-Tibā'ah wa al-Nasyr wa al-Tauzī', 2000.

Syarifudin, Amir. Pelaksanaan Hukum Kewarisan Islam Dalam Lingkungan Adat Minangkabau, Cet. Ke-1. Jakarta: Gunung Agung, 1984.

Umar, Nasaruddin. Argumen Kesetaraan Gender Perspektif Al-Qur'an. 2nd ed. Jakarta: Paramadina, 2001.

Wadud, Amina. Qur'an Menurut Perempuan: Meluruskan Bias Gender Dalam Tradisi Tafsir . Terj. Abdullah Ali. Jakarta: Serambi, 2001. 